\title{
Methods of Chemical and Thermochemical Processing of Hydrolytic Lignin
}

\author{
Irina G. Sudakova ${ }^{a}$, \\ Alexander V. Levdansky and Boris N. Kuznetsov*a, b \\ anstitute of Chemistry and Chemical Technology SB RAS \\ FRC "Krasnoyarsk Science Center SB RAS" \\ Krasnoyarsk, Russian Federation \\ ${ }^{b}$ Siberian Federal University \\ Krasnoyarsk, Russian Federation
}

Received 13.04.2021, received in revised form 12.05.2021, accepted 05.06.2021

\begin{abstract}
The analysis of the latest publications on the use of hydrolytic lignin, which is a largetonnage waste of wood chemical processing, was carried out. In its original form, the hydrolytic lignin is used as fuel, fuel briquettes and pellets, binders and adhesives, organic fertilizers, fillers and enterosorbents. The processing of hydrolytic lignin by chemical and thermochemical methods allows to significantly expand the range of valuable products obtained from it. They are used in chemical, oil and gas and construction industries, metallurgy and other areas. Hydrolytic lignin is most widely used for the production of carbon sorbents. Recently, methods of thermochemical processing of lignin into porous carbon materials with the required texture and strength characteristics as well as into valuable organic products have been developed.
\end{abstract}

Keywords: hydrolytic lignin, processing, chemical, thermochemical, functional biopolymers, carbon sorbents, organic products.

Citation: Sudakova I.G., Levdansky A.V., Kuznetsov B.N. Methods of chemical and thermochemical processing of hydrolytic lignin, J. Sib. Fed. Univ. Chem., 2021, 14(2), 263-275. DOI: 10.17516/1998-2836-0236

(C) Siberian Federal University. All rights reserved

This work is licensed under a Creative Commons Attribution-NonCommercial 4.0 International License (CC BY-NC 4.0).

* Corresponding author E-mail address: bnk@icct.ru 


\title{
Методы химической и термохимической переработки гидролизного лигнина
}

\author{
И. Г. Судакова ${ }^{a}$, А. В. Левданский ${ }^{a}$, Б. Н. Кузнецов ${ }^{\mathrm{a}, \boldsymbol{\sigma}}$ \\ ${ }^{a}$ Институт химии и химической технологии СО РАН \\ ФИЦ «Красноярский научный изентр СО РАН» \\ Российская Федерация, Красноярск \\ ${ }^{6}$ Сибирский федеральный университет \\ Российская Федерация, Красноярск
}

\begin{abstract}
Аннотация. Проведен анализ последних публикаций по использованию гидролизного лигнина, который является крупнотоннажным отходом химической переработки древесины. В исходной форме гидролизный лигнин применяется в различных отраслях промышленности в качестве топлива, топливных брикетов и пеллет, связующих и клеящих веществ, органических удобрений, наполнителей и энтеросорбентов. Переработка гидролизного лигнина химическими и термохимическими методами позволяет существенно расширить ассортимент получаемых из него востребованных продуктов. Они применяются в нефтегазовой и химической промышленности, строительстве, металлургии и других областях. Наиболее широко используется гидролизный лигнин для получения углеродных сорбентов. В последнее время развиваются методы термохимической переработки лигнина с получением пористых углеродных материалов с требуемыми текстурными и прочностными характеристиками, а также ценных органических продуктов.
\end{abstract}

Ключевые слова: гидролизный лигнин, переработка, химическая, термохимическая, функциональные биополимеры, углеродные сорбенты, органические продукты.

Цитирование: Судакова, И.Г. Методы химической и термохимической переработки гидролизного лигнина / И.Г. Судакова, А. В. Левданский, Б. Н. Кузнецов // Журн. Сиб. федер. ун-та. Химия, 2021, 14(2). С. 263-275. DOI: 10.17516/1998-2836-0236

\section{Введение}

Одним из крупнотоннажных отходов химической переработки древесины является гидролизный лигнин (ГЛ). Только в России в отвалах накоплены десятки миллионов тонн отходов гидролизного лигнина, которые могут легко самовозгораться с выделением сернистых, азотистых и других токсичных соединений [1]. При этом он загрязняет почву, поверхностные и подземные воды [2].

На нескольких заводах лигнины сжигают в энергетических установках для снижения транспортных и энергетических расходов. Однако гидролизный лигнин имеет повышенное содержание серы и высокую влажность (от 50 до 75 \%) [3], поэтому его сжигание связано с затратами на дополнительную сушку и приводит к увеличению выбросов оксидов серы. Поэтому все большее внимание уделяется изучению альтернативных методов его утилизации [3-7]. 
Гидролизный лигнин (ГЛ) имеет неоднородный и сложный состав, который зависит от вида сырья и применяемых технологических режимов гидролиза [1]. В нем содержится собственно лигнин, значительно измененный при гидролизе (40-88 \% мас.), трудногидролизируемые полисахариды (13-45 \% мас.), смолистые и гуминоподобные вещества (5-19 \% мас.), зольные элементы (0,5-10 \% мас.). Также в нем присутствует часть сохранившихся при гидролизе моносахаридов, остатки минеральных и органических кислот, следы фурфурола и 5-гидроксиметилфурфурола, азотистые и другие вещества. По своей структуре ГЛ существенно отличается от нативного лигнина древесины и является наиболее конденсированным полимером из всех технических лигнинов. Продолжительный кислотный гидролиз при высоких температу$\operatorname{pax}\left(160-190{ }^{\circ} \mathrm{C}\right)$ и давлении (0,8-1,0 МПа) приводит к образованию прочной трехмерной сети полиядерных ароматических структур и значительному снижению реакционной способности лигнина. Гидролизный лигнин содержит значительно меньше функциональных групп, чем нативный лигнин исходной лигноцеллюлозной биомассы [3].

Примеры успешного использования технических лигнинов, в том числе и гидролизного, в промышленности описаны в ряде обзорных публикаций [6-8].

Переработка технических лигнинов, которые являются многообещающим источником новых товарных продуктов и химических веществ, включает направления по получению продуктов без химической модификации и направления, которые предполагают глубокое изменение его химической структуры [6].

Целью данного обзора являлся анализ новой научно-технической информации для выбора наиболее рациональных и перспективных методов химической и термохимической переработки гидролизного лигнина в востребованные продукты.

\section{Использование немодифицированного гидролизного лигнина}

На основе гидролизного лигнина организован выпуск медицинского препарата «Полифепан», который обладает высокой адсорбционной способностью по отношению к различным патогенным микроорганизмам [9], и предложены новые лечебные препараты «Билигнины», которые селективно адсорбируют желчные кислоты и 3-липопротеиды.

Гидролизный лигнин может переходить в вязкопластическое состояние при давлении 100 МПа, что предопределило направление его применения в качестве брикетированного топлива [10].

Возможно использование гидролизного лигнина в сельском хозяйстве в качестве органических и органоминеральных удобрений, обогащенных азотом и микроэлементами. По мере разложения введенного в почву гидролизного лигнина происходит постепенное высвобождение находящегося в нем азота, что создает условия для равномерного питания растений в течение всего вегетационного периода [6].

Предложено использовать гидролизный лигнин в качестве модификатора для получения асфальтобетонов [11]. Благодаря наличию активных функциональных групп лигнин обладает высокой адгезией к битуму и обеспечивает повышенную водостойкость асфальтобетона и его устойчивость к образованию трещин.

Гидролизный лигнин может быть непосредственно введен в структуру полимерной матрицы с целью улучшения свойств полимера [12]. В частности, лигнин смешивают с полио-

$$
-265-
$$


лефинами (полиэтилен и полипропилен) и ароматическими полимерами (полистирол) для получения упаковочных пленок [13-15]. С использованием добавок лигнина были разработаны новые материалы для 3D-печати [16] и антипирены [17].

Возможности промышленного применения немодифицированного гидролизного лигнина весьма ограничены из-за его низких эксплуатационных и потребительских свойств. Однако переработка гидролизного лигнина химическими и термохимическими методами позволяет существенно расширить ассортимент получаемых из него функциональных полимеров и химических продуктов [18].

\section{Химическая модификаџия гидролизного лигнина}

Наличие остаточных функциональных групп в гидролизном лигнине делает возможным его контролируемую химическую модификацию. Методы химической функционализации лигнина основываются прежде всего на реакционной способности его фенольных и спиртовых гидроксильных групп. В работе [8] рассмотрены возможности функционализации ароматической части фенилпропановых звеньев лигнина наряду с реакциями функционализации с участием гидроксильных групп.

Реакция гидроксиалкилирования фенольных групп с использованием формальдегида в присутствии сильного основания, такого как $\mathrm{NaOH}$, используется для получения фенольных смол. Лигнин может заменить часть токсичного фенола в производстве лигнин-фенолформальдегидных смол при изготовлении древесных композиционных материалов [19].

Путем аминирования по реакции Манниха получают аминированный лигнин, который может использоваться в качестве поликатионных полимеров или поверхностно-активных веществ [20].

Введением нитрогруппы в ароматическое кольцо получают нитролигнин, используемый в качестве компонента буровых растворов, допированных азотом углеродных материалов [21], он может применяться и для производства удобрений пролонгированного действия [22].

Гидролизный лигнин не только легко нитруется, но и легко хлорируется. Хлорлигнин используется как заменитель природных дубителей, в качестве адсорбента для извлечения редкоземельных металлов из производственных растворов, понизитель вязкости буровых растворов, как флотореагент в обогатительной практике. Кроме того, хлорлигнин придает биологическую и атмосферную стойкость техническим тканям [7].

Функционализация лигнина путем его этерификации включает реакции гидроксильных групп лигнина с лактидами [23], лактонами [24], ангидридами [25], карбоновыми кислотами [26]. Лигнин, модифицированный реакциями с карбоновыми кислотами, использовали в составе нового гидрогеля, который проявляет антибактериальные свойства и применяется для адресной доставки гидрофобных лекарств [27]. Ацетилирование используют для того, чтобы улучшить смешиваемость лигнина с неполярными веществами или увеличить растворимость лигнина в органических растворителях [28]. Силилирование лигнина позволяет улучшить термические свойства и растворимость модифицированного лигнина [29].

Среди реакций этерификации для химической модификации лигнина наиболее известна реакция с оксидом пропилена, «оксипропилирование» $[8,30]$. Основным применением полученного оксипропилированного лигнина является синтез жестких пенополиуретанов.

$$
-266-
$$


Реакции фенолирования могут использоваться для создания новых фенольных групп в лигнине [31]. Эта реакция часто используется при синтезе лигнин-фенол-формальдегидных смол, поскольку количество реакционных центров в гидролизном лигнине при этом существенно возрастает.

Одним из перспективных направлений модификации лигнина является сульфатирование, которое придает ему способность растворяться в воде и увеличивает его биоразлагаемость. Сульфатированные производные лигнина могут найти применение в фармацевтике как потенциальные противовирусные препараты и антикоагулянты нового класса [32, 33].

В результате окисления гидролизного лигнина азотной кислотой были получены биологически активные продукты - хинонные нитрополикарбоновые кислоты (ХНПК). Аммонийные соли ХНПК являются стимуляторами роста и увеличивают урожайность ряда овощных культур и картофеля [6].

Фторированный лигнин - эффективная добавка в шихту на основе железного порошка, предназначенная для изготовления изделий методом порошковой металлургии [6].

После аммонолиза гидролизного лигнина в нем значительно увеличивается содержание карбоксильных и общих ОН-групп. Эти группы принимают участие в процессах ионообмена и комплексообразования с оксидами и гидроксидами железа, что позволяет превратить ржавчину в стабильные водонерастворимые продукты. Получаемый из гидролизного лигнина продукт выполняет двоякую роль: преобразователя ржавчины и преобразователя грунта, по которому наносят защитные лакокрасочные покрытия [5].

\section{Термохимическая переработка гидролизного лигнина}

Наиболее изученные термохимические методы переработки гидролизного лигнина - пиролиз без доступа воздуха, гидрогенизация в среде водорода, акватермолиз в среде воды, термическое растворение в органических растворителях [34].

Пиролиз основан на термохимическом разложении лигнина при нагревании до $500-800{ }^{\circ} \mathrm{C}$ без доступа кислорода. В результате терморазложения образуются смолы пиролиза, которые представляют собой сложные смеси ароматических и кислородсодержащих соединений, газообразные продукты $\left(\mathrm{CO}, \mathrm{CO}_{2}, \mathrm{CH}_{4}\right.$ и т. д) и твердый остаток [35]. Для получения преимущественно жидких продуктов проводится быстрый пиролиз в присутствии катализаторов, что позволяет превращать лигнин в жидкие продукты с выходом последних до 70 \% [36]. Твердый остаток пиролиза представляет собой высокоуглеродистый пористый материал.

В работе [37] показано, что в процессе совместного пиролиза гидролизного лигнина и полипропилена при температуре $400{ }^{\circ} \mathrm{C}$ гидролизный лигнин увеличивает степень превращения синтетического полимера в легкокипящие жидкие продукты при низком газообразовании. Влияние лигнина проявляется также и в увеличении содержания в жидких продуктах углеводородов $\mathrm{C}_{9}$ - и $\mathrm{C}_{3}$-олефинов. Легкокипящие жидкие продукты совместного пиролиза полипропилена и гидролизного лигнина можно использовать в качестве сырья для получения ценных химических соединений и компонентов моторных топлив.

Состав жидких продуктов термических превращений различных лигнинов, а также их смесей с полиэтиленом и полипропиленом изучен в работе [38]. Установлено, что жидкие продукты термического превращения гидролизного лигнина характеризуются повышенным со-

$$
-267-
$$


держанием ароматических и полиароматических углеводородов. Продукты совместного превращения гидролизного лигнина с полиэтиленом или полипропиленом обогащены веществами алифатической природы и имеют пониженное содержание полиароматических соединений в высококипящих фракциях.

Термическое растворение лигнина в органических растворителях в присутствии муравьиной кислоты позволяет получать смеси алкилированных фенолов и углеводородов $\mathrm{C}_{8}-\mathrm{C}_{10} \mathrm{c}$ очень низким содержанием кислорода, что дает возможность использования их в качестве компонентов моторного топлива [39]. Для повышения конверсии лигнина в жидкие и газообразные продукты при терморастворении часто применяются различные катализаторы и низшие спирты в составе растворителя [40, 41]. Чаще всего процессы термического растворения гидролизного лигнина в органических растворителях приводят к образованию преимущественно высококипящих продуктов с повышенным содержанием кислорода. В дальнейшем эти продукты должны подвергаться каталитическому крекингу и гидрооблагораживанию для получения моторных топлив.

Гидрогенизация лигнинов под давлением водорода позволяет получить легкокипящие продукты и снизить содержание в них кислорода. К недостаткам гидрогенизационных методов можно отнести большое потребление водорода.

Поскольку гидролизный лигнин является высококонденсированным биополимером и по содержанию твердого углерода превосходит древесину, он служит хорошим сырьем для производства углеродных сорбентов.

Разработаны различные технологии получения углеродных сорбентов из гидролизного лигнина, которые основаны на методах физической и химической активации $[42,43]$. Физическая активация проводится в два этапа, включающих карбонизацию сырья и активацию карбонизованного продукта водяным паром или диоксидом углерода. Химическая активация основана на одностадийной термообработке исходного углеродного сырья химическими веществами (кислотами, щелочами, солями металлов и др.). При химической активации обычно образуются углеродные материалы с более высокой поверхностью и объемом микропор, чем при физической активации.

Гидролизный лигнин может быть пиролизован в токе аргона в микропористый углеродный сорбент с выходом 50 \% при нагревании до $900{ }^{\circ} \mathrm{C}$ [44]. Карбонизованный материал, полученный при скорости нагрева $1{ }^{\circ} \mathrm{C} /$ мин, имел удельную площадь поверхности $530 \mathrm{~m}^{2} / \Gamma$, которая увеличилась до $740 \mathrm{~m}^{2} /$ г после промывки углеродного продукта водой.

Кратковременной (несколько секунд) термообработкой измельченного гидролизного лигнина в псевдоожиженном слое оксидного $\mathrm{Al}-\mathrm{Cu}-\mathrm{Cr}$ катализатора при температурах $670-820^{\circ} \mathrm{C}$ получены углеродные материалы с развитой пористой структурой [45]. Осуществлен подбор условий карбонизации гидролизного лигнина и активации углеродного продукта, обеспечивающих получение качественных углеродных материалов (объем пор до 0,9 см³/г, удельная поверхность 750-800 м²/г) с выходом 15-19 \% относительно массы сухого лигнина.

Изучено влияние режимов карбонизации и последующей активации водяным паром на микроструктуру и молекулярно-ситовые свойства гранулированных пористых углеродных материалов, полученных из гидролизного лигнина [46]. Установлено, что скорость нагрева менее $3{ }^{\circ} \mathrm{C} /$ мин способствует образованию в углеродном продукте микропор размером $0,56-$

$$
-268-
$$


0,58 нм при температуре карбонизации $700{ }^{\circ} \mathrm{C}$. При скорости нагрева более $3{ }^{\circ} \mathrm{C} / \mathrm{Mин}$, образуются микропоры размером 0,70-0,78 нм. Активация угля из лигнина водяным паром при $800{ }^{\circ} \mathrm{C}$ приводит к образованию активных углей с более развитым объемом микропор и размером $0,6-0,66$ нм. Эти активные угли обладают молекулярно-ситовыми свойствами и способны отделять гелий от метана в смесях $\mathrm{He}-\mathrm{CH}_{4}$.

Путем карбонизации гидролизного лигнина при 600-700 ${ }^{\circ} \mathrm{C}$ получены микропористые углеродные материалы с минимальным размером микропор [47]. При последующей парогазовой активации карбонизированных образцов лигнина происходит «растравливание» микропор с получением активных углей с удельной поверхностью $865 \mathrm{~m}^{2} /$ г и объемом микропор $0,37 \mathrm{~cm}^{3} /$ г.

Углеродные сорбенты, приготовленные термообработкой модифицированного $\mathrm{H}_{3} \mathrm{PO}_{4}$ лигнина, имеют площадь поверхности до 700 м²/г, объем микро- и мезопор варьирует до $0,45 \mathrm{~cm}^{3} / \Gamma$ [48]. Активность полученных пористых материалов в сорбции ионов металлов (никеля, железа, хрома и кремния) и фенольных соединений сравнима с активностью промышленных углеродных сорбентов. Также они могут эффективно использоваться для удаления красителей из водных растворов.

Показана возможность получения путем термохимической активации гидролизного лигнина с гидроксидом натрия и калия при $800{ }^{\circ} \mathrm{C}$ углеродных сорбентов с развитой пористой структурой, пригодных для использования в различных областях [49].

В работе [50] сопоставлены различные методы активации и модификации гидролизного лигнина: щелочная активация, карбоксиметилирование, аминирование, термообработка на разных стадиях модификации, используемые для создания нужных функциональных групп и регулирования пористой структуры получаемых углеродных сорбентов.

Преимуществами методов химической активации являются сокращение продолжительности активирования сырья, повышенный выход пористых углеродных материалов и их высокие адсорбционные свойства [51].

С использованием метода термически индуцированного разделения фаз были получены углеродные сорбенты на основе смеси лигнина и полипропилена [52]. Полученные пористые материалы сорбируют масла примерно в 2 раза больше по сравнению с полипропиленом. Они являются перспективными сорбентами для ликвидации последствий разлива нефти, включая очистку почвы от нефтяных загрязнений (табл. 1).

\section{Заключение}

Выполняемые научные исследования по утилизации гидролизного лигнина в основном направлены на совершенствование уже существующих методов переработки с получением лигноугля, углеродных сорбентов, топливных пеллет и на использование гидролизного лигнина в качестве частичной замены фенола в фенолформальдегидных смолах и для производства удобрений. Высокотехнологическая переработка гидролизного лигнина осложняется неоднородностью его состава и строения, плохой растворимостью в традиционных растворителях.

Использование методов химической модификации гидролизного лигнина позволяет существенно расширить области его применения в нефтяной и газовой промышленности в качестве компонентов буровых растворов, при производстве композиционных материалов, в химической промышленности, строительстве и агропромышленном комплексе.

$$
-269-
$$


Таблица 1. Применение продуктов переработки гидролизного лигнина

Table 1. Application of products of hydrolysis lignin processing

\begin{tabular}{|c|c|c|c|}
\hline Область применения & Продукт & Модификация & Ссылка \\
\hline В качестве топлива & $\begin{array}{l}\text { Гидролизный лигнин. } \\
\text { Топливные брикеты, пеллеты. } \\
\text { Топочный газ }\end{array}$ & $\begin{array}{l}\text { Отсутствует. } \\
\text { Отсутствует. } \\
\text { Пиролиз }\end{array}$ & {$[10,34-36]$} \\
\hline Производство сорбентов & $\begin{array}{l}\text { Пористые углеродные } \\
\text { материалы. } \\
\text { Ионообменные смолы }\end{array}$ & $\begin{array}{l}\text { Пиролиз, карбонизация, } \\
\text { активация. } \\
\text { Электрохимическое } \\
\text { окисление }\end{array}$ & {$[6,42-52]$} \\
\hline $\begin{array}{l}\text { Агропромышленный } \\
\text { комплекс }\end{array}$ & $\begin{array}{l}\text { Гидролизный лигнин } \\
+ \text { минеральные удобрения. } \\
\text { Аммонийные соли }\end{array}$ & $\begin{array}{l}\text { Отсутствует. } \\
\text { Отсутствует. } \\
\text { Окисление }\end{array}$ & {$[6,22]$} \\
\hline $\begin{array}{l}\text { Нефтяная и газовая } \\
\text { промышленность }\end{array}$ & $\begin{array}{l}\text { Хлорлигнин. } \\
\text { Нитролигнин, игетан, сунил }\end{array}$ & $\begin{array}{l}\text { Хлорирование и } \\
\text { нитрование }\end{array}$ & {$[7,21]$} \\
\hline Строительство & $\begin{array}{l}\text { Нитролигнин. } \\
\text { Грунт для лакокрасочных } \\
\text { покрытий. } \\
\text { Компонент для } \\
\text { пенополиуретанов }\end{array}$ & $\begin{array}{l}\text { Нитрование. } \\
\text { Аммонолиз. } \\
\text { Оксипропилирование }\end{array}$ & {$[5,8,21,30]$} \\
\hline Дорожное строительство & Гидролизный лигнин & Отсутствует & [11] \\
\hline Металлургия & $\begin{array}{l}\text { Лигнобрикеты. } \\
\text { Фторированный лигнин }\end{array}$ & $\begin{array}{l}\text { Отсутствует. } \\
\text { Электрохимическое } \\
\text { окисление }\end{array}$ & {$[10,30]$} \\
\hline $\begin{array}{l}\text { Производство } \\
\text { композиционных } \\
\text { материалов }\end{array}$ & $\begin{array}{l}\text { Адгезивы (клеи), связующее и } \\
\text { антипирены. } \\
\text { Древесные композиты }\end{array}$ & $\begin{array}{l}\text { Фенолирование. } \\
\text { Отсутствует }\end{array}$ & {$[13-17,19,31]$} \\
\hline $\begin{array}{l}\text { Химическая } \\
\text { промышленность }\end{array}$ & $\begin{array}{l}\text { Жидкие продукты - } \\
\text { прекурсоры для получения } \\
\text { химических веществ и } \\
\text { моторных топлив }\end{array}$ & $\begin{array}{l}\text { Деполимеризация путем } \\
\text { окисления, пиролиза, } \\
\text { терморастворения, } \\
\text { гидрогенизации }\end{array}$ & [37-41] \\
\hline $\begin{array}{l}\text { Фармацевтическая } \\
\text { промышленность }\end{array}$ & $\begin{array}{l}\text { Полифепан. } \\
\text { Билигнины. } \\
\text { Сульфатированный } \\
\text { гидролизный лигнин }\end{array}$ & $\begin{array}{l}\text { Отсутствует. } \\
\text { Отсутствует. } \\
\text { Сульфатирование }\end{array}$ & {$[9,27,32,33]$} \\
\hline
\end{tabular}

Развиваются исследования, направленные на разработку эффективных методов деполимеризации гидролизного лигнина и его смесей с другими видами органического сырья с получением ценных органических продуктов, включая компоненты моторных топлив.

\section{Благодарности / Acknowledgments}

Работа выполнена при финансовой поддержке Российского фонда фундаментальных исследований, Правительства Красноярского края и краевого фонда науки (грант № 20-43-242904) в рамках Государственного задания ИХХТ СО РАН ФИЦ КНЦ СО РАН, проект 0287-2021-0017, с использованием оборудования Красноярского регионального центра коллективного пользования ФИЦ КНЦ СО РАН. 
This work was supported by the Russian Foundation for Basic Research, the Krasnoyarsk Territory Government and the edge of Science Foundation (grant no. 20-43-242904) within the framework of the state task ICCT SB RAS, project 0287-2021-0017, using the equipment of Krasnoyarsk Regional Research Equipment Centre of SB RAS.

\section{Список литературы / References}

1. Rabinovich M.L. Lignin by-products of Soviet hydrolysis industry: Resources, characteristics and utilization as a fuel. Cell. Chem. Technol. 2014. Vol. 48(7-8), P. 613-631.

2. Krutov S.M., Voznyakovskii A.P., Gordin A.A., Savkin D.I., Shugalei I.V. Environmental problems of wood biomass processing. Waste processing lignin. Russ. J. Gen. Chem. 2015. Vol. 85(13), P. 2898-2907.

3. Цветков М.В., Салганский Е.А. Лигнин: Направления использования и способы утилизации (обзор). Журнал прикладной химии 2018. Т. 91(7), С. 988-997. [Tsvetkov M.V., Salganskiy E.A. Lignin: Directions of use and methods of disposal (review). Journal of Applied Chemistry 2018. Vol. 91(7), P. 988-997. (In Russ.)]

4. Lora J.H., Glasser W.G. Recent industrial applications of lignin: A sustainable alternative to non-renewable materials. J. Polym. Environ 2002. Vol. 10(1-2), P. 39-48.

5. Кузнецов Б.Н. Переработка лигнина в ценные химические продукты и нанопористые материалы. Красноярск: Сиб. федер. ун-т, 2018. 152 с. [Kuznetsov B.N. Processing of lignin into valuable chemical products and nanoporous materials. Krasnoyarsk, Sib. Feder. un-t, 2018. 152 p. (In Russ.)]

6. Крутов С.М., Возняковский А.П., Грибков И.В., Шугалей И.В. Пути решения проблемы лигниновых отходов: прошлое, настоящее и будущее. Экологическая химия 2014. Т. 23(3), С. 145158. [Krutov S.M., Voznyakovsky A.P., Gribkov I.V., Shugaley I.V. Ways to solve the problem of lignin waste: past, present and future. Environmental Chemistry 2014. Vol. 2(3), P. 145-158. (In Russ.)]

7. Симонова В.В., Шендрик Т.Г., Кузнецов Б.Н. Методы утилизации технических лигнинов. Журнал Сибирского федерального университета. Химия 2010. T. 4(3), С. 340-354. [Simonova V.V., Shendrik T.G., Kuznetsov B.N. Methods for utilization of technical lignins. Journal of Siberian Federal University. Chemistry 2010. Vol. 4(3), P. 340-354. (In Russ.)]

8. Bertella S., Luterbacher J.S. Lignin Functionalization for the Production of Novel Materials. Trends in Chemistry 2020. Vol. 2(5), P. 440-453. doi:10.1016/j.trechm.2020.03.001

9. Маркелов Д.А., Ницак О.В., Геращенко И.И. Сравнительное изучение адсорбционной активности медицинских сорбентов. Химико-фармащевтический журнал. 2008. Т. 42(7), С. 30-33. doi.org/10.30906/0023-1134-2008-42-7-30-33. [Markelov D.A., Nitsak O.V., Gerashchenko I.I. Comparative study of the adsorption activity of medical sorbents. Pharmaceutical Chemistry Journal 2008. Vol. 42(7), P. 30-33. doi.org/10.30906/0023-1134-2008-42-7-30-33. (In Russ.)]

10. Воробьев В.П., Голунов А.Д., Игнатьев А.В. Углеродистые восстановители ферросплавного производства. Альтернативные решения. Сталь 2008. № 8, С. 67-72. [Vorobiev V.P., Golunov A.D., Ignatiev A.V. Carbonaceous reducing agents for ferroalloy production. Alternative solutions. Steel 2008. № 8, P. 67-72. (In Russ.)]

11. Дошлов О.И, Казарян А.С., Дошлов И.О. Новые аспекты утилизации технического гидролизного лигнина в качестве сырья для промышленного производства. Вестник ИрГТУ 2014. T. 11(94), C. 205-210. [Doshlov O.I., Kazaryan A.S., Doshlov I.O. New aspects of utilization of tech- 
nical hydrolysis lignin as a raw material for industrial production. Vestnik ISTU 2014. Vol. 11(94), P. 205-210. (In Russ.)]

12. Laurichesse S., Avérous L. Chemical modification of lignins: Towards biobased polymers. Progress in Polymer Science 2014. Vol. 39(7), P. 1266-1290. doi:10.1016/j.progpolymsci.2013.11.004

13. Alexy P., Košíková B., Podstránska G. The effect of blending lignin with polyethylene and polypropylene on physical properties. Polymer 2000. Vol. 41(13), P. 4901-4908. doi:10.1016/s00323861(99)00714-4

14. Matsushita Y. Conversion of technical lignins to functional materials with retained polymeric properties. Journal of Wood Science 2015. Vol. 61(3), P. 230-250. doi:10.1007/s10086-015-1470-2

15. Domínguez-Robles J., Larrañeta E., Fong M.L., Martin N.K., Irwin N.J., Mutjé P., Tarrés Q., Delgado-Aguilar M. Lignin/poly(butylene succinate) composites with antioxidant and antibacterial properties for potential biomedical applications. International Journal of Biological Macromolecules 2019. № 145, P. $92-99$ doi:10.1016/j.ijbiomac.2019.12.146

16. Tanase-Opedal M., Espinosa E., Rodríguez A., Chinga-Carrasco G. Lignin: A Biopolymer from Forestry Biomass for Biocomposites and 3D Printing. Materials 2019. Vol. 12(18), P. 3006. doi:10.3390/ma12183006

17. Mandlekar N., Cayla A., Rault F., Giraud S., Salaün F., Guan, J. Development of Novel Polyamide 11 Multifilaments and Fabric Structures Based on Industrial Lignin and Zinc Phosphinate as Flame Retardants. Molecules 2020. Vol. 25(21), P. 4963. doi:10.3390/molecules25214963

18. Wang H., Pu Y., Ragauskas A., Yang B. From Lignin to Valuable Products-Strategies, Challenges, and Prospects. Bioresource Technology 2019. No. 271, P. 449-461. doi:10.1016/j.biortech.2018.09.072

19. Yang S., Zhang Y., Yuan T.-Q., Sun R.-C. Lignin-phenol-formaldehyde resin adhesives prepared with biorefinery technical lignins. Journal of Applied Polymer Science 2015. Vol. 132(36), P. 1-8. doi:10.1002/app.42493

20. Du X., Li J., Lindström M.E. Modification of industrial softwood kraft lignin using Mannich reaction with and without phenolation pretreatment. Industrial Crops and Products 2014. No 52, P. 729-735. doi:10.1016/j.indcrop.2013.11.035

21. Graglia M., Pampel J., Hantke T., Fellinger T.-P., Esposito D. Nitro Lignin-Derived NitrogenDoped Carbon as an Efficient and Sustainable Electrocatalyst for Oxygen Reduction. ACS Nano 2016. Vol. 10(4), P. 4364-4371. doi:10.1021/acsnano.5b08040

22. Jiao G.-J., Xu Q., Cao S.-L., Peng P., She D. Controlled-Release Fertilizer with Lignin Used to Trap Urea/Hydroxymethylurea/ Urea-Formaldehyde Polymers. BioResources 2018. Vol. 13(1), P. 17111728. doi:10.15376/biores.13.1.1711-1728

23. Chung Y.-L., Olsson J.V., Li R.J., Frank C.W., Waymouth R.M., Billington S.L., Sattely E.S. A Renewable Lignin-Lactide Copolymer and Application in Biobased Composites. ACS Sustain. Chem. Eng. 2013. Vol. 1(10), P. 1231-1238. doi:10.1021/sc4000835

24. Abdollahi M., Bairami Habashi R., Mohsenpour M. Poly( $\varepsilon$-caprolactone) chains grafted from lignin, hydroxymethylated lignin and silica/lignin hybrid macroinitiators: Synthesis and characterization of lignin- based thermoplastic copolymers. Industrial Crops and Products 2019. No. 130, P. $547-$ 557. doi:10.1016/j.indcrop.2019.01.012

25. Liu L.-Y., Hua Q., Renneckar S. A simple route to synthesize esterified lignin derivatives. Green Chem. 2019. Vol. 21, P. 3682-3692. doi:10.1039/c9gc00844f 
26. Koivu K.A.Y., Sadeghifar H., Nousiainen P.A., Argyropoulos D.S., Sipilä J. Effect of Fatty Acid Esterification on the Thermal Properties of Softwood Kraft Lignin. ACS Sustain. Chem. Eng. 2016. Vol. 4(10), P. 5238-5247. doi:10.1021/acssuschemeng.6b01048

27. Larrañeta E., Imízcoz M., Toh J.X., Irwin N.J., Ripolin A., Perminova A., ... Donnelly R.F. Synthesis and Characterization of Lignin Hydrogels for Potential Applications as Drug Eluting Antimicrobial Coatings for Medical Materials. ACS Sustain. Chem. Eng. 2018. Vol. 6(7), P. 9037-9046. doi:10.1021/acssuschemeng.8b01371

28. Sameni J., Krigstin S., Sain M. Solubility of Lignin and Acetylated Lignin in Organic Solvents. BioResources 2019. No. 18, P. 1548-1565. doi:10.15376/biores.

29. Buono P., Duval A., Verge P., Averous L., Habibi Y. New Insights on the Chemical Modification of Lignin: Acetylation versus Silylation. ACS Sustain. Chem.Eng. 2015. Vol. 4(10), P. 5212-5222. doi:10.1021/acssuschemeng.6b00903

30. Zakzeski J., Bruijnincx P.C.A., Jongerius A.L., Weckhuysen B.M. The Catalytic Valorization of Lignin for the Production of Renewable Chemicals. Chem. Rev. 2010. Vol. 110, P. 3552-3599

31. Podschun J., Stücker A., Saake B., Lehnen R. Structure-Function Relationships in the Phenolation of Lignins from Different Sources. ACS Sustain. Chem. Eng. 2015. Vol. 3(10), P. 2526-2532. doi:10.1021/acssuschemeng.5b00705

32. Raghuraman A., Tiwari V., Zhao Q., Shukla D., Debnath A.K., Desai U.R. Viral Inhibition Studies on Sulfated Lignin, a Chemically Modified Biopolymer and a Potential Mimic of Heparan Sulfate. Biomacromolecules 2007. Vol. 8(5), P. 1759-1763. doi: 10.1021/bm0701651

33. Henry B.L., Desai U.R. Sulfated low molecular weight lignins, allosteric inhibitors of coagulation proteinases via the heparin binding site, significantly alter the active site of thrombin and factor xa compared to heparin. Thrombosis Research 2014. Vol. 134(5), P. 1123-1129. doi:10.1016/j. thromres.2014.08.024

34. Zevallos Torres L.A., Lorenci Woiciechowski A., de Andrade Tanobe V.O., Karp S.G., Guimarães Lorenci L.C., Faulds C., Soccol C.R. Lignin as a potential source of high-added value compounds: A review. Journal of Cleaner Production 2020. 121499. doi:10.1016/j.jclepro.2020.121499

35. Fan L., Zhang Y., Liu S., Zhou N., Chen P., Cheng Y., ... Ruan R. Bio-oil from fast pyrolysis of lignin: Effects of process and upgrading parameters. Bioresource Technology 2017. No. 241, P. 1118-1126. doi:10.1016/j.biortech.2017.05.129

36. Ma Z., Ghosh A., Asthana N., van Bokhoven J. Optimization of the Reaction Conditions for Catalytic Fast Pyrolysis of Pretreated Lignin over Zeolite for the Production of Phenol. ChemCatChem 2017. Vol. 9(6), P. 954-961. doi:10.1002/cctc.201601674

37. Шарыпов В.И., Береговцова Н.Г., Кузнецов Б.Н., Барышников С.В., Marin N., Weber J.V. Получение легкокипящих углеводородных смесей совместным пиролизом полипропилена и гидролизного лигнина. Химия в интересах устойчивого развития 2003. Т. 11(2), С. 429-436. [Sharypov V.I., Beregovtsova N.G., Kuznetsov B.N., Baryshnikov S.V., Marin N., Weber J.V. Obtaining low-boiling hydrocarbon mixtures by joint pyrolysis of polypropylene and hydrolysis lignin. Chemistry for Sustainable Development 2003. Vol. 11 (2), P. 429-436. (In Russ.)]

38. Береговцова Н.Г., Шарыпов В.И., Кузнецов Б.Н. Исследование состава жидких продуктов термических превращений лигнина. Журнал Сибирского федерального университета. Химия 2010. № 1. C. 36-44. [Beregovtsova N.G., Sharypov V.I., Kuznetsov B.N. Study of the composi-

$$
-273-
$$


tion of liquid products of thermal transformations of lignin. Journal of the Siberian Federal University. Chemistry 2010. No. 1, P. 36-44. (In Russ.)]

39. Xu W., Miller S.J., Agrawal P.K., Jones C.W. Depolymerization and Hydrodeoxygenation of Switchgrass Lignin with Formic Acid. ChemSusChem 2012. Vol. 5(4), P. 667-675. doi:10.1002/ cssc. 201100695

40. Kim J.-Y., Park J., Hwang H., Kim J.K., Song I.K., Choi J.W. Catalytic depolymerization of lignin macromolecule to alkylated phenols over various metal catalysts in supercritical tert-butanol. Journal of Analytical and Applied Pyrolysis 2015. No. 113, P. 99-106. doi:10.1016/j. jaap.2014.11.011

41. Yoshikawa T., Yagi T., Shinohara S., Fukunaga T., Nakasaka Y., Tago T., Masuda T. Production of phenols from lignin via depolymerization and catalytic cracking. Fuel Processing Technology 2013. Vol. 69-75, No. 108. doi:10.1016/j.fuproc.2012.05.003

42. Suhas Carrott P.J.M., Ribeiro Carrott M.M.L. Lignin - from natural adsorbent to activated carbon: A review. Bioresource Technology 2007. Vol. 98(12), P. 2301-2312. doi:10.1016/j. biortech.2006.08.008

43. Черкашина Н.И., Ерофеев В.А. Физико-химический метод модифицирования сорбционных материалов на основе лигнина. Энергетические установки и технологии 2017. Т. 3(1), C. 136-143. [Cherkashina N.I., Erofeev V.A. Physicochemical method of modification of sorption materials based on lignin. Power Plants and Technologies 2017. Vol. 3(1), P. 136-143. (In Russ.)]

44. Еремина А.О., Головина В.В., Чесноков Н.В., Кузнецов Б.Н. Углеродные адсорбенты из гидролизного лигнина для очистки сточных вод от органических примесей. Журнал Сибирского федерального ун-та. Химия 2011. Т. 4(1), С. 100-107. [Eremina A.O., Golovina V.V., Chesnokov N.V., Kuznetsov B.N. Carbon Adsorbents from Hydrolytic Lignin for Waste Waters Purification from Organic Contaminations. Journal of Siberian Federal University. Chemistry 2011. V. 4(1), P. 100-107. (In Russ.)]

45. Kuznetsov B.N., Shchipko M.L., Chesnokov N.V. Porous carbons obtained from lignite, anthracite and graphite in a bed of slag and catalyst particles. Journal of Siberian Federal University. Chemistry 2009. Vol. 2(2), P. 93-101.

46. Baklanova O.N., Plaksin G.V., Drozdov V.A., Duplyakin V.K., Chesnokov N.V., Kuznetsov B.N. Preparation of microporous sorbents from cedar nutshells and hydrolytic lignin. Carbon 2003. No. 41, Р. 1793-1800.

47. Бакланова О.Н., Плаксин Г.В., Дроздов В.А. Микропористые углеродные сорбенты на основе растительного сырья. Российский химический журнал 2004. Т. 48(3), С. 89-94. [Baklanova O.N., Plaksin G.V., Drozdov V.A. Microporous carbon adsorbents based on vegetable raw materials. Russian Chemical Journal 2004. Vol. 48(3). P. 89-94. (In Russ.)]

48. Kriaa A., Hamdi N., Srasra E. Removal of Cu (II) from water pollutant with Tunisian activated lignin prepared by phospohoric acid activation. Desalination 2010. Vol. 250(1). P. 179-187.

49. Белецкая М.Г, Богданович Н.И., Кузнецова Л.Н., Саврасова Ю.А. Методы термохимической активации в синтезе активных углей из технических лигнинов. ИВУЗ. «Лесной журнал» 2011. № 6, C. 144-148. [Beletskaya M.G., Bogdanovich N.I., Kuznetsova L.N., Savrasova Yu.A. Methods of thermochemical activation in the synthesis of active carbons from technical lignins. IVUZ. "Forest Journal” 2011. No. 6, P. 144-148. (In Russ.)] 
50. Хитрин К.С., Хитрин С.В., Фукс С.Л., и др. Влияние физической и химической модификации на сорбционную способность гидролизного лигнина. Журн. прикл. химии 2012. Т. 85(8), C. 1258-1261. [Khitrin K.S., Khitrin S.V., Fuks S.L. et al. Influence of physical and chemical modification on the sorption capacity of hydrolytic lignin. Journal of Applied Chemistry 2012. Vol. 85(8), P. 1258-1261. (In Russ.)]

51. Hayashi J., Kazehaya A., Muroyama K., Watkinson A.P. Preparation of activated carbons from lignin by chemical activation. Carbon 2000. No. 38. P. 1873-1878.

52. Alassod A., Gibril M., Islam S.R., Huang W., Xu G. Polypropylene/lignin blend monoliths used as sorbent in oil spill cleanup. Heliyon 2020. Vol. 6(9), e04591. doi:10.1016/j.heliyon.2020.e04591 